\title{
Disruption of beta3 adrenergic receptor increases susceptibility to DIO in mouse
}

\author{
Nailliw Z Preite 1,2, Bruna P P do Nascimento',2, Cynthia R Muller3, \\ Anna Laura V Américo3, Talita S Higa4, Fabiana S Evangelista4, \\ Carmen L Lancellotti5, Felipe dos Santos Henriques, \\ Miguel Luiz Batista Jr6, Antonio C Bianco ${ }^{7}$ and Miriam O Ribeiro' \\ ${ }^{1}$ Center of Biological and Health Sciences, Mackenzie Presbyterian University, Sao Paulo, SP, Brazil \\ 2Department of Translational Medicine, EPM, Federal University of Sao Paulo, Sao Paulo, SP, Brazil \\ ${ }^{3}$ Experimental Pathophysiology Department, Faculty of Medicine, University of Sao Paulo, SP, Brazil \\ ${ }^{4} 5$ chool of Arts, Sciences and Humanities, University of Sao Paulo, Sao Paulo, SP, Brazil \\ 5Department of Pathology, School of Medical Sciences, Santa Casa, São Paulo, SP, Brazil \\ 6Laboratory of Adipose Tissue Biology, Integrated Group of Biotechnology, University of Mogi das \\ Cruzes, Mogi das Cruzes, SP, Brazil \\ 7Division of Endocrinology and Metabolism, Department of Internal Medicine, Rush University and \\ Medical Center, Chicago, Illinois, USA
}

Correspondence should be addressed to M O Ribeiro Email

miriamribeiro@mackenzie.br

\begin{abstract}
The brown adipose tissue (BAT) mediates adaptive changes in metabolic rate by responding to the sympathetic nervous system through $\beta$-adrenergic receptors (AR). Here, we wished to define the role played by the $A R \beta_{3}$ isoform in this process. This study focused on the $A R \beta_{3}$ knockout mice ( $\left.A R \beta_{3} K O\right)$, including responsiveness to cold exposure, diet-induced obesity, intolerance to glucose, dyslipidaemia and lipolysis in white adipose tissue (WAT). AR $\beta_{3} \mathrm{KO}$ mice defend core temperature during cold exposure $\left(4^{\circ} \mathrm{C}\right.$ for $5 \mathrm{~h}$ ), with faster BAT thermal response to norepinephrine (NE) infusion when compared with wild-type (WT) mice. Despite normal BAT thermogenesis, $A R \beta_{3} \mathrm{KO}$ mice kept on a high-fat diet (HFD; $40 \%$ fat) for 8 weeks exhibited greater susceptibility to diet-induced obesity, markedly increased epididymal adipocyte area with clear signs of inflammation. The HFD-induced glucose intolerance was similar in both groups but serum hypertriglyceridemia and hypercholesterolemia were less intense in $A R \beta_{3} \mathrm{KO}$ animals when compared with WT controls. Isoproterenol-induced lipolysis in isolated white adipocytes as assessed by glycerol release was significantly impaired in $A R \beta_{3} \mathrm{KO}$ animals despite normal expression of key proteins involved in lipid metabolism. In conclusion, $A R \beta_{3}$ inactivation does not affect BAT thermogenesis but increases susceptibility to dietinduced obesity by dampening WAT lipolytic response to adrenergic stimulation.
\end{abstract} Key Words
- obesity
- lipolysis
- adaptive thermogenesis
- brown adipose tissue
- $\beta_{3}$ adrenergic receptor

\section{Introduction}

A balance between food intake and energy expenditure is essential to preserve fuel homeostasis. Changes in caloric intake trigger physiological responses that include adaptive modifications in appetite, metabolic rate and energy expenditure in order to preserve the energy levels in the body (Weigle 1994). In small mammals of all ages and in human newborns, adaptive changes in metabolic rate triggered by cold exposure or feeding on a

Published by Bioscientifica Ltd. 
high-caloric diet occur mainly in the brown adipose tissue (BAT), a specialized tissue that has the ability to dissipate energy in the form of heat (Cannon \& Nedergaard 2004, Lidell \& Enerback 2010). A significant portion of human adults also exhibit a functional BAT (Cinti 2006, van der Lans et al. 2014), with incidence and activity inversely correlated to ambient temperature, age and body fat content (Lidell \& Enerback 2010, Kajimura \& Saito 2014), indicating a possible role of this tissue in adult human energy metabolism (Lowell \& Spiegelman 2000, Cypess et al. 2009).

Indeed, several studies have shown that the active BAT in healthy adult humans is influenced by cold exposure (van Marken Lichtenbelt et al. 2009, Kajimura \& Saito 2014, van der Lans et al. 2014), increasing energy expenditure. These findings indicate that metabolically active BAT may participate in the control of the energy balance and adiposity in humans, as already confirmed in small rodents (Yoneshiro et al. 2011). Thereby, adult human BAT represents a promising target for anti-obesity therapeutic strategies, however, its physiological relevance remains controversial (Cinti 2006, Hibi et al. 2016).

Autonomic regulation of BAT is influenced by environmental temperature and energy levels of the body. These signals are centrally integrated and, as a result, there is autonomic discharge of norepinephrine (NE) in BAT that stimulates energy expenditure and local thermogenesis. This is the result of NE interacting with $\beta$ adrenergic receptors (AR $\beta$ ), triggering a sequence of events that result in cAMP accumulation, hydrolysis of triglycerides, mitochondrial uncoupling protein 1 $\left(\mathrm{UCP}_{1}\right)$ activation, all of which are necessary for BAT thermogenesis (for review see Silva (2011)). Thus, NE and other catecholamines are the main mediators of diet and cold-induced adaptive thermogenesis (Silva 2011).

Norepinephrine acts primarily through three AR $\beta$ isoforms, $\mathrm{AR} \beta_{1}, \mathrm{AR} \beta_{2}$ and $\mathrm{AR} \beta_{3}$, the latter being the most abundant isoform expressed in mice adipose tissue. The WAT of these animals exhibits AR $\beta$ mRNA at ratios of approximately 3:1:150 for the AR $\beta_{1}, A R \beta_{2}$ and $A R \beta_{3}$ isoforms, respectively (Collins et al. 1994). Notably, mice with triple knockout for $A R \beta_{1}, A R \beta_{2}$ and $A R \beta_{3}\left(A R \beta_{1-3} \mathrm{KO}\right)$ are obese and intolerant to cold exposure (Bachman et al. 2002, Jimenez et al. 2002), exhibiting markedly lower $\mathrm{UCP}_{1}$ levels (Bachman et al. 2002). In addition, based largely on the phenotypic characterization of animals with single AR $\beta$ knockouts, it is well accepted that lipolysis and adaptive thermogenesis are mediated via $\operatorname{AR} \beta_{1}$ and $\operatorname{AR} \beta_{3}$, while the $A R \beta_{2}$ subtype plays only a minor role in these processes (Mattsson et al. 2011, Ueta et al. 2012, Fernandes et al. 2014). For example, $A R \beta_{1} \mathrm{KO}$ animals exhibit normal basal metabolic rate but are deficient in both cold- and diet-induced thermogenesis (Ueta et al. 2012). In contrast, $\mathrm{AR} \beta_{2} \mathrm{KO}$ mice have normal BAT thermogenesis but do exhibit lower body weight (Chruscinski et al. 1999) and disruption of glucose homeostasis (Santulli et al. 2012, Fernandes et al. 2014).

The relatively high level of $A R \beta_{3}$ in adipose tissue supports the idea that this subtype is key for BAT growth (Nagase et al. 1994), lipolysis (Soloveva et al. 1997) and thermogenesis (Susulic et al. 1995). In fact, animals treated with $\mathrm{AR} \beta_{3}$ agonists do exhibit higher BAT activation and energy expenditure (Lidell \& Enerback 2010, Xiao et al. 2015), increased lipid mobilization and reduced body fat (Arch \& Wilson 1996, Atgie et al. 1997, Fisher et al. 1998, Inokuma et al. 2006, Lidell \& Enerback 2010) as well as induction of $\mathrm{UCP}_{1}$ expression (Inokuma et al. 2006). Furthermore, studies in $\mathrm{AR} \beta_{3} \mathrm{KO}$ mice indicate increased adiposity while on chow diet and an accelerated body weight gain while on a high-fat diet (HFD) (Susulic et al. 1995, Revelli et al. 1997). Notably, also in humans, some $\mathrm{AR} \beta_{3}$ mutations are associated with the development of obesity (Widen et al. 1995). However, despite inactivation of the $A R \beta_{3}, A R \beta_{3} \mathrm{KO}$ mice are not cold-sensitive and exhibit normal UCP-1 induction during cold exposure (Susulic et al. 1995, Mattsson et al. 2011). This study was undertaken to investigate the mechanisms of obesity in $\mathrm{AR} \beta_{3} \mathrm{KO}$ mice.

\section{Materials and methods}

\section{Animals and diets}

All experiments were performed following protocols approved by the Institutional Committee on Animal Research at the Center of Biological Sciences and Health, University Presbyterian Mackenzie. Eight-week-old male WT mice and mice with $A R \beta_{3}$ knockout $\left(\mathrm{AR} \beta_{3} \mathrm{KO}\right.$; FVB background) were obtained from Jackson Laboratory and maintained on a 12-h light/darkness cycle, at a temperature of $24^{\circ} \mathrm{C}$ and given food and water ad libitum. Mice were kept on chow diet (1.8 Cal/g; $4 \%$ fat; Nuvilab CR1; Nuvital, Brazil) except for the experiments in which HFD (7.52 Cal/g; 40\% fat; Rhoster, Sao Paulo, SP, Brazil) was used. In this case, before switching to HFD, all mice were fasted for $12 \mathrm{~h}$ and then placed on HFD for 8 weeks. A total number of six mice per group were used in the experiments, unless otherwise specified. Body weight and 
food intake were monitored daily. All drugs were obtained from Sigma Aldrich, unless specified.

\section{Intra-peritoneal glucose tolerance test}

This test was performed in the morning (around $0900 \mathrm{~h}$ ) on the following groups: WT (control group - WT mice fed with chow diet), WT HFD (WT mice fed with HFD), $\mathrm{AR} \beta_{3} \mathrm{KO}\left(\mathrm{AR} \beta_{3} \mathrm{KO}\right.$ mice fed with chow diet $)$ and $\mathrm{AR} \beta_{3} \mathrm{KO}$ HFD ( $A R \beta_{3} \mathrm{KO}$ mice fed with HFD). Mice were fasted for $12 \mathrm{~h}$ and given glucose $(2 \mathrm{~g} / \mathrm{kg}$ of body weight; i.p.). Blood glucose was measured using a glucometer (One Touch Ultra, Johnson \& Johnson) in blood samples collected from the tail at 0 (before glucose injection), 30, 60, 90 and 120 min after glucose injection (Asensio et al. 2005).

\section{Cold exposure}

Conscious mice (5 WT and $7 \quad \mathrm{AR}_{3} \mathrm{KO}$ ) were housed individually in cages with no bedding and exposed to cold $\left(4^{\circ} \mathrm{C}\right)$ in a chamber with controlled temperature (Eletrolab, Sao Paulo, SP, Brazil) for $5 \mathrm{~h}$. Colonic temperature was measured at hourly intervals using a high-precision thermometer connected to a rectal probe of $3 \mathrm{~mm}$ diameter (YSI 402, YSI, Yellow Springs, OH, USA) (Enerback et al. 1997).

\section{Interscapular BAT (BAAT) thermal response to the NE infusion}

WT and $\mathrm{AR} \beta_{3} \mathrm{KO}$ mice that had been kept at room temperature (6 and 3, respectively) were anaesthetized with urethane $(560 \mathrm{mg} / \mathrm{kg}$; i.p.) and chloralose $(38 \mathrm{mg} / \mathrm{kg}$; i.p.) and had one jugular vein cannulated with a polyethylene (P-50) cannula. iBAT temperature $\left({ }^{\circ} \mathrm{C}\right)$ was monitored using a precalibrated thermistor probe (YSI 427 Skin, Yellow Springs, OH, USA) surgically placed under the iBAT pad (Ribeiro et al. 2001, Bianco et al. 2014). Throughout the experiment, the animals were maintained on a warm pad to stabilize body temperature. After a stable baseline was reached (approximately $5 \mathrm{~min}$ ), $\mathrm{NE}$ infusion $(2 \mathrm{mg} / \mathrm{mL})$ was started using an infusion pump (model 2274, Harvard Apparatus, Holliston, MA, USA) at a rate of $8 \mu \mathrm{g} / \mathrm{kg} / \mathrm{min}$ for $30 \mathrm{~min}$.

\section{WAT lipolysis}

Samples of approximately $250 \mathrm{mg}$ of epididymal WAT from WT and $\mathrm{AR} \beta_{3} \mathrm{KO}$ mice fed with chow diet or HFD
(5-6 per group) were excised, minced and digested with collagenase as described previously in the presence of adenosine deaminase (ADA, Sigma, $0.2 \mathrm{U} / \mathrm{mL}, \mathrm{pH}$ 7.45) (Rodbell 1964, Susulic et al. 1995). Cells were then exposed to ascorbic acid or isoproterenol (Sigma Chemical). The rate of lipolysis was estimated by measuring the release of glycerol (Sigma Chemical) and expressed as nmol.10-6 cells.h-1 ${ }^{-1}$ Cells were also kept on $10 \%$ formaldehyde for subsequent measurement adipocyte diameter. Total adipocyte volume used in each reaction was estimated with a haematocrit card. Adipocyte diameter and total volume were used as internal references.

\section{Blood chemistry}

Serum cholesterol and triglycerides were measured using clinical kits (Cholesterol Liquiform, Labtest, Brazil; Triglycerides Liquiform, Labtest).

\section{mRNA analysis by real-time PCR (RT-qPCR)}

Total BAT and WAT RNA were extracted using TRIzol (Invitrogen) and used to synthesize cDNA with the SuperScript First-Strand Synthesis System Kit (Invitrogen) in a Mastercycler thermocycler (Eppendorf, Hamburg, Germany). About 120 ng of cDNA were used as template in the Real-Time PCR reaction, using the kit QuantiTect SYBR Green PCR (Qiagen). Each cycle included $2 \mathrm{~min}$ at $50^{\circ} \mathrm{C}, 15 \mathrm{~min}$ at $95^{\circ} \mathrm{C}, 15 \mathrm{~s}$ at $94^{\circ} \mathrm{C}, 30 \mathrm{~s}$ at $60^{\circ} \mathrm{C}, 30 \mathrm{~s}$ at $72^{\circ} \mathrm{C}, 15 \mathrm{~s}$ at $95^{\circ} \mathrm{C}, 15 \mathrm{~s}$ at $55^{\circ} \mathrm{C}$ and $15 \mathrm{~s}$ at $95^{\circ} \mathrm{C}$ for 50 cycles. The relative expressions of $A R \beta_{1}$ and $A R \beta_{2}$ were expressed as a function of the housekeeping gene $\beta$-actin for WT and $\mathrm{AR} \beta_{3} \mathrm{KO}$ mice (4-7 per group).

\section{Western blotting}

$20 \mu \mathrm{g}$ BAT mitochondrial protein or total protein of WAT of WT and $A R \beta_{3} \mathrm{KO}$ mice fed with chow diet or HFD (3-5 per group) were size fractionated using $12 \%$ SDS-PAGE, transferred to a nitrocellulose membrane and probed with $\mathrm{UCP}_{1}$ (1:5000 dilution), HSL, p-HSL, AMPk, p-AMPK, ATGL, perilipin and DGAT2 goatpolyclonal IgG primary antibody solution (1:1000 dilution) (Santa Cruz Biotechnology), and $\beta$-actin (1:2000 dilution) (ABCAM) was used as a loading control. The secondary antibody solution used was donkey anti-goat IgG conjugate HRP (Santa Cruz Biotechnology), in a 1:2000 dilution.

Published by Bioscientifica Ltd. 


\section{Histology}

Samples of WAT and liver of all the four groups of WT and $\mathrm{AR} \beta_{3} \mathrm{KO}$ mice were excised, fixed in $10 \%$ buffered formaldehyde for $24 \mathrm{~h}$, embedded in paraffin and sectioned.

\section{Morphological analysis}

The sequential $5 \mu \mathrm{m}$ sections obtained were first stained with haematoxylin-eosin (H\&E) and then, with Picrosirius red. The sections were analyzed with a Leica microscope (DM 750), equipped with filters to provide circularly polarized light. Picrosirius red staining sections allowed collagen fibres detection with different colours (Batista et al. 2016). Type I collagen fibres appear orange to red, whereas the thinner type III collagen fibres were stained with a yellow to a green hue. Tissue images were obtained with an $\times 40$ objective lens, recorded on a digital camera (DFC 295, Leica), displayed on a high-resolution monitor (LG, Flatron, E1941) and analyzed with SigmaScan Pro image analysis (Chicago, IL, USA). Measurement of adipocyte size (as the area in $\mu \mathrm{m}^{2}$ ) was acquired by Imagen Pro-Plus 6.0 (100 adipocytes per stained section) and performed with a custom-designed software programme written using MATLAB (v. R2010b; The MathWorks, Natick, MA, USA).

\section{Immunohistochemistry}

Immunohistochemistry of epididymal WAT samples were carried out with sections fixed in buffered formalin and embedded in paraffin. Deparaffinized sections $(5 \mu \mathrm{m})$ were stained with $\mathrm{H} \& \mathrm{E}$. After quenching of endogenous peroxidase activity with $0.3 \% \mathrm{H}_{2} \mathrm{O}_{2}$ in methanol and blocking of free protein-binding sites with 5\% normal goat serum, sections were immune stained for immune cells: macrophages with CD68 anti-mouse KP-1 monoclonal antibody (Abcam, ab955), neutrophils with CD11b (Abcam, ab75476) and TNFo (Abcam, ab6671) antibodies. Specific secondary antibodies were peroxidase (horseradish peroxidase) conjugated. Histochemical reactions were performed using Vecta stain ABC Kit.

\section{Statistical analysis}

Student's $t$-test or one-way ANOVA followed by StudentNewman-Keuls test were used throughout as indicated (GraphPad Software). For brown fat thermogenic response, we used linear regression analysis. For lipolysis assay, two-way ANOVA was used followed by StudentNewman-Keul's test. $P<0.05$ was used to reject the null hypothesis. All results were expressed as mean \pm standard error of the mean.

\section{Results}

\section{$A R \beta_{3} K O$ mice have normal adiposity and defend core temperature during acute cold exposure}

When acutely exposed to cold $\left(4^{\circ} \mathrm{C}\right), \mathrm{AR} \beta_{3} \mathrm{KO}$ mice maintain core temperature for up to $5 \mathrm{~h}$ (Fig. 1A), reflecting their ability to maintain thermal homeostasis. This is not explained by better insulation (given their propensity to obesity (Susulic et al. 1995, Revelli et al. 1997, Lowell 1998)), that is, we found $\mathrm{AR} \beta_{3} \mathrm{KO}$ mice consume similar amounts of calories (Fig. 1B) and grow normally, reaching adulthood with similar body weight (Fig. 1C) and similar adiposity as assessed by the area of the epididymal adipocytes to WT controls.

\section{$A R \beta_{3} K O$ iBAT responds faster to NE infusion}

To assess adaptive thermogenesis and test BAT directly, $\mathrm{AR} \beta_{3} \mathrm{KO}$ animals were infused with NE and iBAT thermal response evaluated. In the WT animals, a typical iBAT
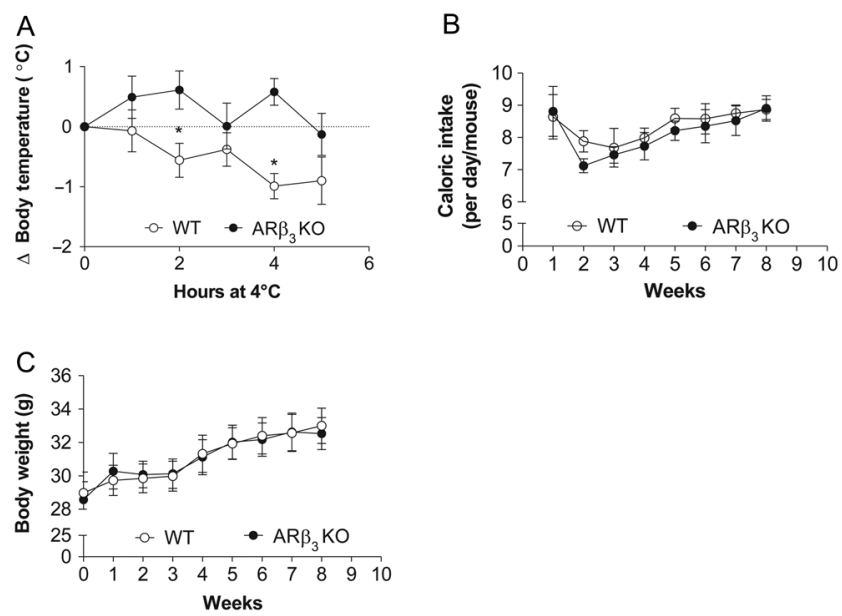

Figure 1

(A) Variation in body temperature of WT and $A R \beta_{3} \mathrm{KO}$ mice fed with chow diet during cold exposure $\left(4^{\circ} \mathrm{C}\right)$ for $5 \mathrm{~h}(n=6)$. * vs WT with $P<0.01$; (B) caloric intake per mouse/day of the WT and $A R \beta_{3} \mathrm{KO}$ mice treated with chow diet along the weeks of treatment - values on the graph are an average of values obtained during the days of the week $(n=6)$; (C) body weight of the WT and $A R \beta_{3} \mathrm{KO}$ animals during the treatment with chow diet $(n=6)$. All values are expressed as mean \pm SEM and data were analyzed using Student's $t$-test.

Published by Bioscientifica Ltd. 
A
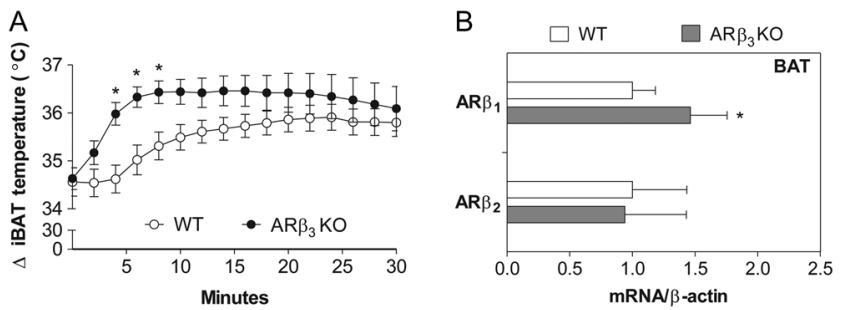

C

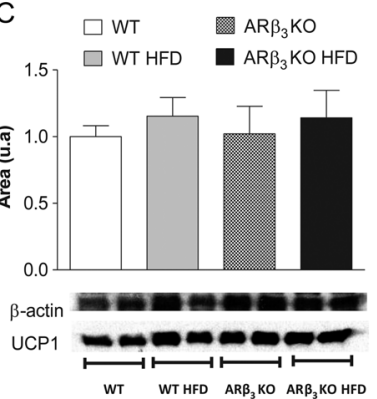

Figure 2

(A) Variation of the iBAT temperature in WT and $A R \beta_{3} \mathrm{KO}$ animals exposed to 30 min infusion of NE $(n=6)$; (B) mRNA levels of AR $\beta_{1}$ and AR $\beta_{2}$ on iBAT of the WT and $A R \beta_{3}$ KO mice treated with chow diet $(n=6)$. * vs WT with $P<0.05$. Values expressed as mean \pm SEM and data were analyzed using Student's $t$-test.

thermal response was detected as early as $5 \mathrm{~min}$ of the start of the NE infusion, plateauing at about $20 \mathrm{~min}$ with maximum delta temperature of about $1.5^{\circ} \mathrm{C}$ (Fig. $2 \mathrm{~A}$ ). In contrast, the response in the $\mathrm{AR} \beta_{3} \mathrm{KO}$ animals was much faster ( $1 \mathrm{~min})$, with a plateau that was reached by $5 \mathrm{~min}$ at about $2.0^{\circ} \mathrm{C}$ (Fig. $2 \mathrm{~A}$ ). The nonlinear regression analysis indicates that the top best-fit value for the $\mathrm{AR} \beta_{3} \mathrm{KO}$ curve is $36.36 \pm 0.041$ vs $35.76 \pm 0.046^{\circ} \mathrm{C}$ in WT control animals, with a respective $\log _{50}$ of 3.5 vs $7.8 \mathrm{~min}(P<0.009)$. Notably, these differences between $A R \beta_{3} \mathrm{KO}$ and WT controls were observed even as the iBAT mitochondrial UCP-1 levels remained similar in both groups of animals (Fig. 2C). This could be explained by compensatory increase in other AR $\beta$ isoforms (Susulic et al. 1995) and indeed there was an approximately $45 \%$ increase in iBAT AR $\beta_{1}$ mRNA levels, whereas the AR $\beta_{2}$ mRNA levels remained similar to WT control animals (Fig. 2B).

\section{$A R \beta_{3} \mathrm{KO}$ mice exhibit greater susceptibility to diet-induced obesity}

BAT thermogenesis can also be triggered by HFD and, given that NE-induced BAT thermogenesis is better than normal, here we wanted to test whether the $A R \beta_{3} \mathrm{KO}$ animals show greater susceptibility to HFD as reported previously (Susulic et al. 1995, Revelli et al. 1997,
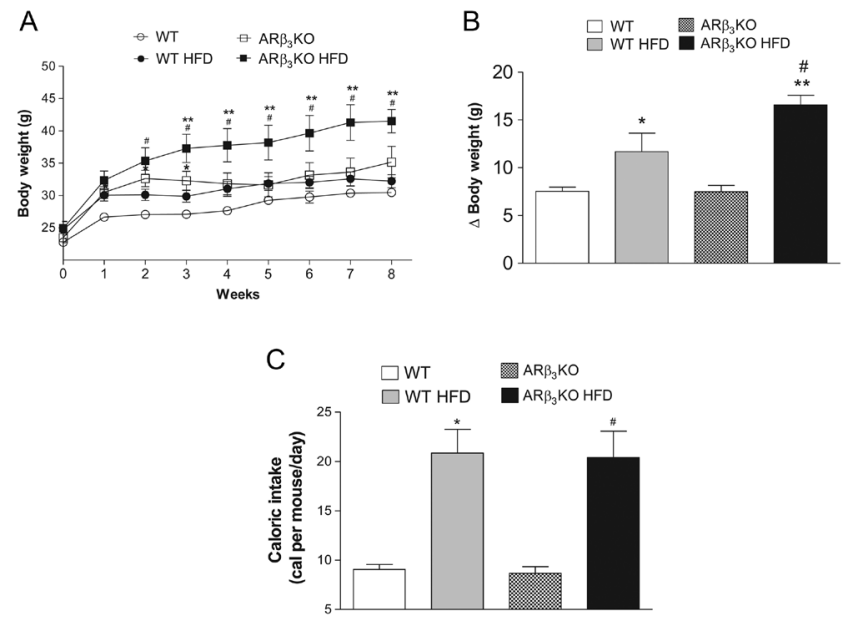

Figure 3

(A) Body weight of WT and $A R \beta_{3} \mathrm{KO}$ treated with chow diet or HFD for 8 weeks $(n=6) ;(B)$ delta body weight of the WT and $A R \beta_{3}$ KO mice treated with chow diet or HFD for 8 weeks $(n=6)$; (C) caloric intake of WT and $\mathrm{AR} \beta_{3} \mathrm{KO}$ treated with chow diet or HFD for 8 weeks $(n=6)$. * vs WT with $P<0.05$; ** vs WT HFD with $P<0.01$; \# vs $A R \beta_{3} \mathrm{KO}$ with $P<0.001$. Values expressed as mean \pm SEM and data were analyzed using one-way ANOVA followed by Student-Newman-Keuls test.

Lowell 1998). Therefore, we revisited this issue by placing $A R \beta_{3} \mathrm{KO}$ animals on a HFD for 8 weeks, and found that they gained significantly more body weight (Fig. 3A and B) despite ingesting the same amount of calories (Fig. 3C). Additionally, $\mathrm{AR} \beta_{3} \mathrm{KO}$ HFD animals exhibited markedly increased epididymal adipocyte size (hypertrophy) of 24.5-fold $(P>0.01)$ when compared with controls $\left(\mathrm{AR} \beta_{3} \mathrm{KO}\right)$. HFD also induced adipocyte hypertrophy in WT (6.9-fold, $P>0.01$ ), compared with WT controls. The adipocyte hypertrophy was 1.6 -fold higher in $\mathrm{AR} \beta_{3} \mathrm{KO}$ group when compared with WT, both fed with HFD (Fig. 4A). To determine the adipocyte size distribution, we measured the two-dimensional area of 100 individual adipocytes from epididymal WAT (Fig. 4B). Consistent with results for average adipocyte size, adipocytes sized between 10 and $70.10^{3} \mu \mathrm{m}$ showing higher frequency in $\mathrm{AR} \beta_{3} \mathrm{KO} \mathrm{HFD}$, besides adipocytes higher than $90.10^{3} \mu \mathrm{m}$ were just detected in $\mathrm{AR} \beta_{3} \mathrm{KO}$ HFD.

\section{WAT inflammation is more pronounced in $A R \beta_{3} \mathrm{KO}$ mice after diet-induced obesity}

Considering the scope of data regarding WAT remodelling induced by HFD, notably throughout adipocyte hypertrophy and the modification in total collagen density (fibrosis) (Sun et al. 2011), we also examined the presence of inflammation and infiltrated cells in epididymal WAT from $A R \beta_{3} \mathrm{KO}$. Immunostaining for macrophages

Published by Bioscientifica Ltd. 
A

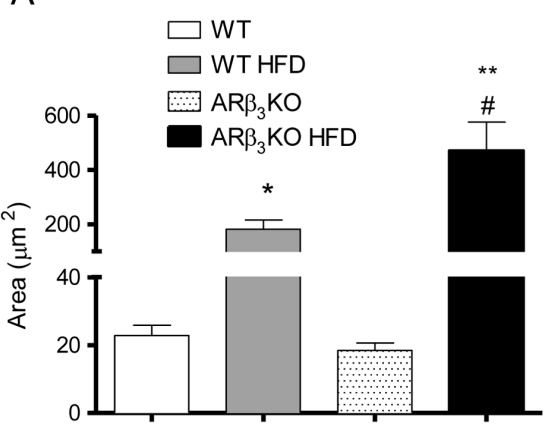

B

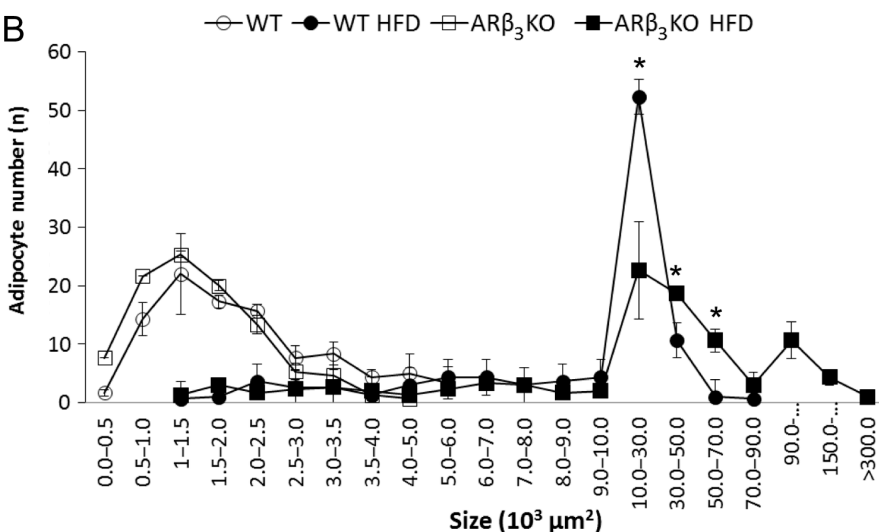

C
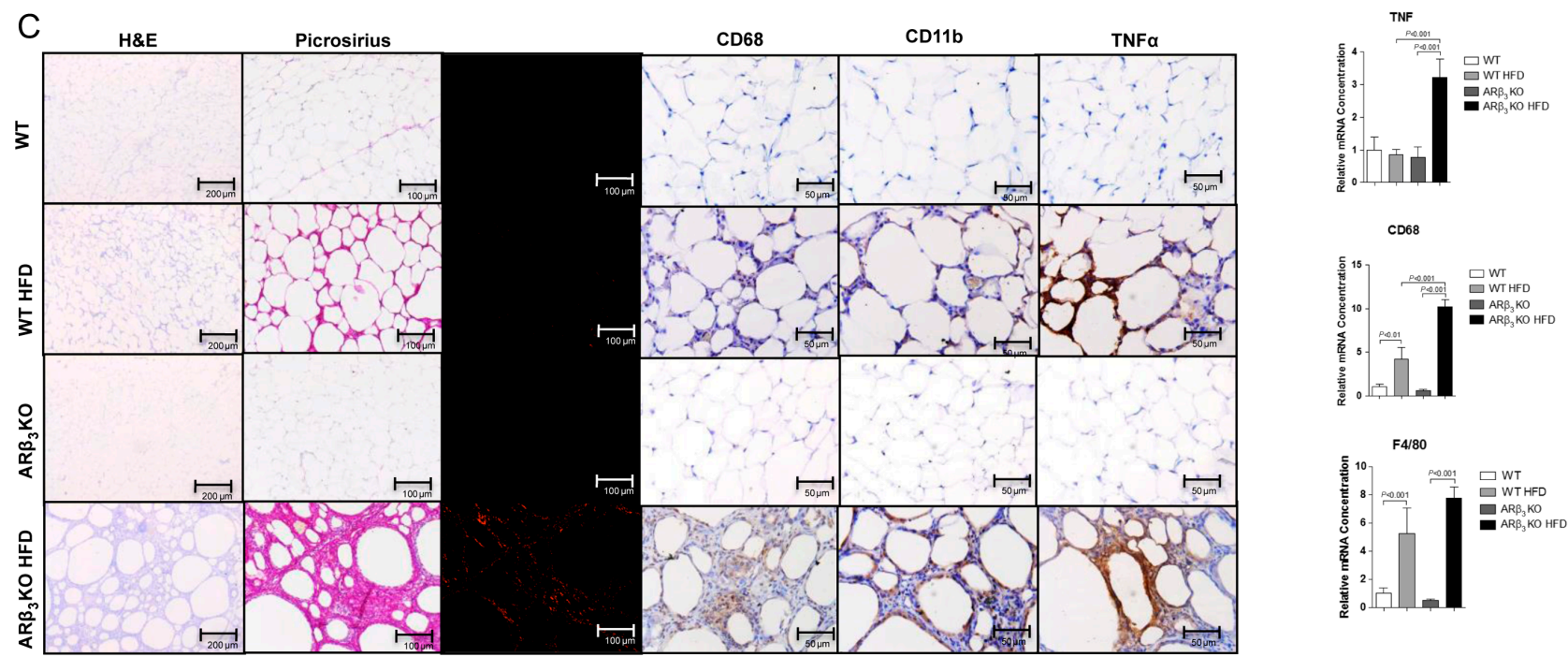

\section{Figure 4}

Morphological and immune-staining characteristics of the WT and AR $\beta_{3}$ KO mice fed with chow diet or HFD for 8 weeks; photomicrographs illustrate the most representative images considering data related to morphometric analysis of sectional area (A) and (B) of adipocytes size distribution (three sections per mice; $n=3$ per group; scale bar: $50 \mathrm{~mm}$ ). (C) H\&E staining; $100 x ;$ Picrosirius red staining. Collagen fibres are presented in different colours. Type I collagen fibres are orange to red; identification of different immune cell types were stained with markers of macrophages (CD68), neutrophils (CD11b) and for TNFo. (D) qPCR analysis of isolated RNA. * vs WT with $P<0.05$; ** vs WT HFD with $P<0.05$ and $\#$ vs AR $\beta_{3}$ KO $P<0.01$. Values expressed as mean \pm SEM. Nuclei were stained with haematoxylin (blue labelling). Bar $(\mu \mathrm{m})$. HE, haematoxylin and eosin staining.

(CD68), neutrophils (CD11b) and TNFo and analysis of gene expression of CD68, F4/80 and TNF $\alpha$ were carried out (Fig. 4C). Additionally, in tissue sections stained for CD11b positive cells, we found the higher intensity that was more pronounced in the surrounding of adipocytes in $\mathrm{AR} \beta_{3} \mathrm{KO}$ HFD. Less frequently, sections for CD68 positive cells showed irregular distribution more often observed in the epididymal WAT fibrotic areas from $\mathrm{AR} \beta_{3} \mathrm{KO}$ HFD. CD68 and F4/80 mRNA expression increased in both HFD-treated groups ( $\sim 5$ and 16 fold, respectively). The former was higher in $\mathrm{AR} \beta_{3} \mathrm{KO}$ when compared with WT HFD ( 4 fold). Increase in TNF $\alpha$ mRNA expression was detected only in $A R \beta_{3} \mathrm{KO} \mathrm{HF}$ (Fig. 4D). No structural differences were found in liver of the $\mathrm{AR} \beta_{3} \mathrm{KO}$ animals while on a chow diet (Fig. 5A and B) and feeding on a
HFD resulted in a severe macrovesicular liver steatosis, with triglyceride accumulation in large hepatocyte vacuoles but similar in WT and $\mathrm{AR} \beta_{3} \mathrm{KO}$ (Fig. $5 \mathrm{C}, \mathrm{D}$ and $\mathrm{E}$ ). HFD-induced glucose intolerance was similar in both groups (Fig. 6) but serum triglycerides and cholesterol increased less in $\mathrm{AR} \beta_{3} \mathrm{KO}$ animals when compared with WT controls, both fed with HFD (Table 1).

\section{WAT lipolysis is impaired in $A R \beta_{3} \mathrm{KO}$ adipocytes}

Next, we studied basal and stimulated lipolysis in isolated white adipocytes of all animals. In WT control cells obtained from animals kept on a chow diet, exposure to the non-selective $\beta$-agonist isoproterenol leads to an approximately 3.6-fold stimulation in glycerol release, 

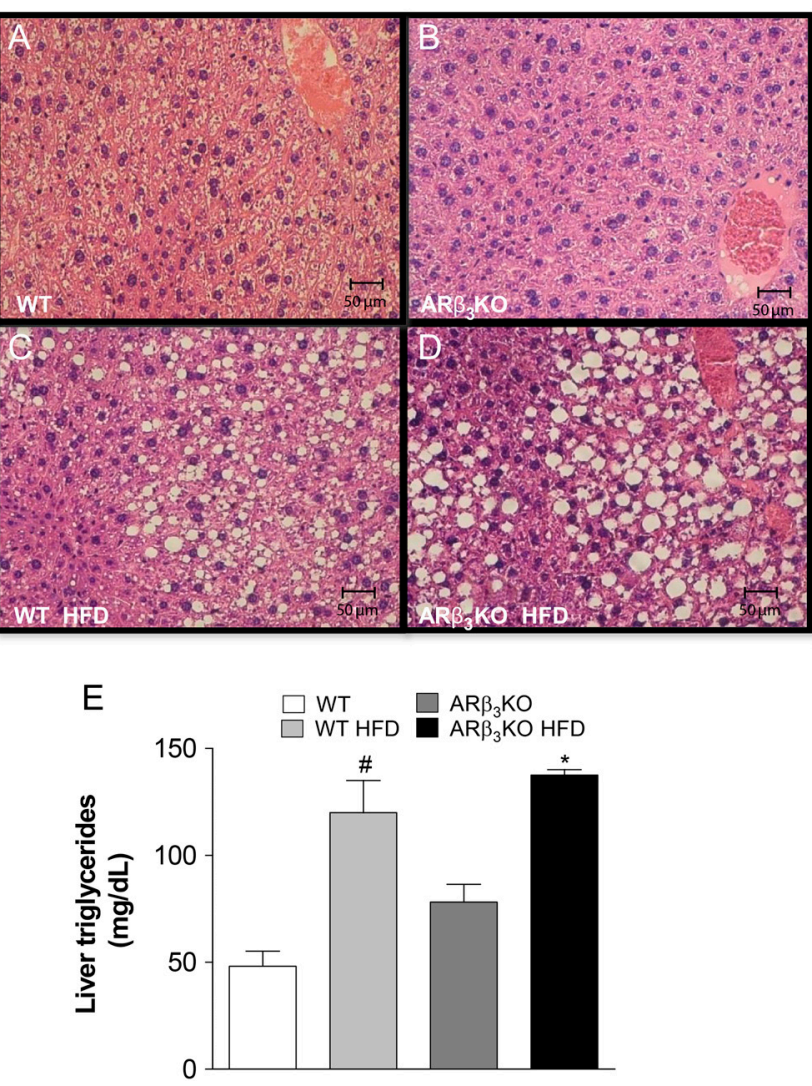

Figure 5

Liver histology of (A) WT mice fed with chow diet (n=6); (B) WT mice fed with HFD $(n=6)$; (C) AR $\beta_{3} \mathrm{KO}$ mice fed with chow diet $(n=6)$; (D) AR $\beta_{3} \mathrm{KO}$ mice fed with HFD for 8 weeks $(n=6)$ and (E) liver triglycerides of WT and $\mathrm{AR} \beta_{3} \mathrm{KO}$ mice treated with chow diet or HFD for 8 weeks $(n=6)$. \# vs WT with $P<0.01$; * vs AR $\beta_{3} \mathrm{KO}$ with $P<0.01$. Values expressed as mean \pm SEM and data were analyzed using one-way ANOVA followed by Student-Newman-Keuls test.

whereas in $\mathrm{AR} \beta_{3} \mathrm{KO}$ cells this figure is only 2.3 -fold, but not significantly different (Table 2). These differences in glycerol release were greatly exaggerated when WT

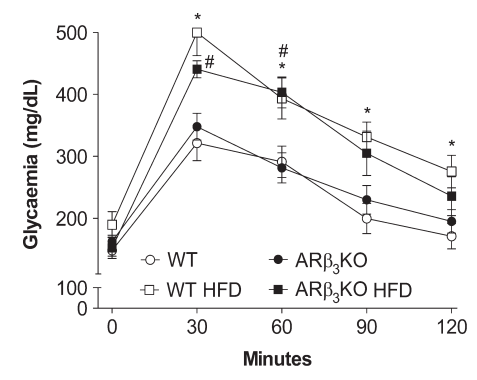

Figure 6

Glucose tolerance test (GTT) of the WT and AR $\beta_{3} \mathrm{KO}$ mice fed with chow diet or HFD for 8 weeks $(n=6)$; blood glucose at 0 (baseline), 30, 60, 90 and $120 \mathrm{~min}$ after glucose injection. * vs WT with $P<0.05$; \# vs AR $\beta_{3} \mathrm{KO}$ with $P<0.05$. Values expressed as mean \pm SEM and data were analyzed using one-way ANOVA followed by Student-Newman-Keuls test. control cells obtained from animals kept on HFD were tested. In this case, the isoproterenol-stimulated glycerol release reached more than twice the levels seen in animals kept on a chow diet (Table 2). In contrast, there was no greater lipolytic response to isoproterenol in the cells obtained from $A R \beta_{3} \mathrm{KO}$ mice kept on a HFD, with levels remaining at less than half of those observed in WT control cells (Table 2). That these differences are the result of $A R \beta_{3}$ inactivation is supported by the observation that the expression level of key proteins involved in lipid metabolism remains unaffected in the epididymal fat of $\mathrm{AR} \beta_{3} \mathrm{KO}$ animals, including HSL and p-HSL, AMPk and p-AMPk, ATGL, perilipin and DGAT2 (Fig. 7).

\section{Discussion}

This study of the $A R \beta_{3} \mathrm{KO}$ mouse revealed two novel findings: first, there is a faster and more intense thermal response of $\mathrm{AR} \beta_{3} \mathrm{KO}$ BAT during infusion with NE, likely reflecting increased expression of $A R \beta_{1}$. This suggests that the increase in $A R \beta_{1}$, which was also seen by others (Susulic et al. 1995), overcompensates for the $\mathrm{AR}_{3}$ inactivation and is able to mediate cAMP production within brown adipocytes. These results explain why the $\mathrm{AR}_{3} \mathrm{KO}$ mouse defends its core temperature when acutely exposed to cold. Secondly, that the greater susceptibility to diet-induced obesity exhibited by these animals is specifically due to $\mathrm{AR} \beta_{3}$ inactivation in white (epididymal) adipocytes, given that the key enzymes involved in lipolysis are normally expressed in these animals (Fig. 7).

It is unexpected that the $\mathrm{AR} \beta_{3} \mathrm{KO}$ mouse is capable of thermoregulation during acute cold exposure (Fig. 1A) (Susulic et al. 1995, Mattsson et al. 2011) in light of the previous studies indicating an important role played by $\mathrm{AR}_{3}$ in adaptive thermogenesis (Carpene et al. 1993, Widen et al. 1995, Atgie et al. 1997, Lafontan et al. 1997, Lowell 1998, Inokuma et al. 2006). The finding that UCP1 levels are normal in $\mathrm{AR} \beta_{3} \mathrm{KO}$ BAT (Fig. 2C) and that the thermal response to catecholamine infusion is better than expected (Fig. 2A) explains the $A R \beta_{3} \mathrm{KO}$ mouse's thermoregulation ability during acute cold exposure. In fact, these findings are reminiscent of the previous observations that the $\mathrm{AR} \beta_{3} \mathrm{KO}$ mouse exhibits normal isoproterenol-induced acceleration of oxygen consumption (Susulic et al. 1995).

While these observations downplay the role played by $\mathrm{AR} \beta_{3}$ in adaptive thermogenesis, these findings highlight a degree of functional redundancy shared by the three AR $\beta$ subtypes, which mitigates the phenotype caused by

Published by Bioscientifica Ltd 
Table 1 Serum cholesterol and triglycerides levels $(\mathrm{mg} / \mathrm{dL})$ of the WT and AR $\beta_{3} \mathrm{KO}$ mice after treatment with chow diet or HFD for 8 weeks.

\begin{tabular}{|c|c|c|c|c|}
\hline & WT & WT HFD & $A R \beta_{3} K O$ & $A R \beta_{3} K O$ HFD \\
\hline Cholesterol & $128.44 \pm 3.26$ & $170.31 \pm 7.48 *$ & $115.36 \pm 5.75$ & $134.64 \pm 4.98^{\#, * *}$ \\
\hline Triglycerides & $127.81 \pm 3.47$ & $167.81 \pm 6.82 *$ & $111.98 \pm 8.6$ & $135.42 \pm 4.77^{\#, * *}$ \\
\hline
\end{tabular}

* vs WT with $P<0.01$; \# vs AR $\beta_{3}$ KO with $P<0.05$; ** Vs WT HFD with $P<0.01$. Values are expressed as mean \pm SEM of 6 animals per group.

the $\mathrm{AR}_{3}$ inactivation (Susulic et al. 1995, Rohrer 1998, Jimenez et al. 2002). Indeed, the $\mathrm{AR} \beta_{3} \mathrm{KO}$ BAT exhibits increased expression of $\operatorname{AR} \beta_{1}$ but not $\operatorname{AR} \beta_{2}$ (Fig. 2B) (Susulic et al. 1995). Given the importance of $\mathrm{AR} \beta_{1}$ in BAT thermogenesis (Ueta et al. 2012), the overexpression of this $\mathrm{AR}$ isoform is likely to explain the normal $\mathrm{AR} \beta_{3} \mathrm{KO}$ BAT phenotype.

Despite better than normal BAT thermogenesis, $\mathrm{AR} \beta_{3} \mathrm{KO}$ animals kept on HFD developed more severe obesity, indicating greater susceptibility to diet-induced obesity. In fact, $\mathrm{AR} \beta_{3} \mathrm{KO}$ animals showed higher levels of adipocyte hypertrophy, followed by severe infiltration of macrophages and increased levels of extracellular matrix components, in particular type I collagen. This scenario suggests that WAT remodelling induced by HFD is a more severe process in $\mathrm{AR} \beta_{3} \mathrm{KO}$. Some studies have demonstrated the relationship regarding the contribution of adipocyte hypertrophy to WAT expansion, in both humans and animal models of obesity (Lee et al. 2014, Rutkowski et al. 2015). Such conditions can lead to a countless of effects, including hypoxia, adipocyte cell death, increased chemokine secretion and dysregulation in fatty acid fluxes (Sun et al. 2011, 2013). Consequently, enhanced macrophage infiltration is required to create an environment for the remodelling process. The end point of WAT remodelling induced by obesity is associated with severe insulin resistance and lipotoxic side effects (Sun et al. 2013). Despite severe WAT remodelling, the $\mathrm{AR} \beta_{3} \mathrm{KO}$ mouse did not exhibit exaggerated intolerance to glucose (Fig. 6), suggesting that $A R \beta_{3}$ could play a role modulating the decrease in insulin sensitivity during high-fat feeding. Also notable was the fact that $\mathrm{AR} \beta_{3} \mathrm{KO}$ animals kept on a HFD exhibited less severe hypercholesterolaemia and hypertriglyceridaemia when compared with WT control animals also kept on HFD (Table 1). This could reflect the greater lipid deposit observed in the $A R \beta_{3} \mathrm{KO}$ WAT and liver. In fact, same obese individuals can preserve systemic insulin sensitivity, as well as obesity-associated lipotoxic side effects, as aforementioned. Such condition is evident even in the presence of WAT expansion, a condition proposed as 'metabolically healthy obese' state (Ruderman et al. 1981). However, the possible role of $\mathrm{AR} \beta_{3}$ deletion in this condition needs further investigation.

Previous studies indicated that the isoproterenolinduced adenylate cyclase activity and lipolysis are diminished in $\mathrm{AR} \beta_{3} \mathrm{KO}$-isolated adipocytes only when adenosine deaminase and the stable adenosine receptor agonist N6-phenylisopropyladenosine (PIA) were used (Susulic et al. 1995). However, the physiological significance of these findings is not clear given that the in vivo lipolytic response to isoproterenol was not affected by the $\mathrm{AR} \beta_{3}$ inactivation (Susulic et al. 1995). These observations led us to hypothesize that a lipolysis defect in WAT could be exacerbated during HFD and thus explain the greater susceptibility of these animals to diet-induced obesity. In fact, $A R \beta_{3} \mathrm{KO}$ isolated adipocytes obtained from HFD animals exhibited less than half of the lipolytic response to isoproterenol as compared with HFD WT controls (Table 2), even though they have normal levels of the key enzymes involved in lipolysis. In contrast, $\mathrm{AR} \beta_{3} \mathrm{KO}$ isolated adipocytes obtained from animals kept on chow diet behaved similarly to WT controls.

Therefore, the observations from this study point to a great physiological relevance for the $A R \beta_{3}$ in the epididymal WAT lipolysis, particularly when the white adipocytes are filled with triglycerides as a result of feeding on a HFD.

Table 2 Differences between basal levels and after stimulation with isoproterenol of glycerol (nmol. $10^{-6}$ cells.h-1) released by isolated white adipocytes of WT and $\mathrm{AR} \beta_{3} \mathrm{KO}$ mice after treatment with chow diet or HFD for 8 weeks.

\begin{tabular}{|c|c|c|c|c|}
\hline & WT & WT HFD & $A R \beta_{3} K O$ & $A R \beta_{3} K O$ HFD \\
\hline Basal levels & $3257 \pm 1056$ & $\begin{array}{c}5221 \pm 990 \\
20242+1768 *\end{array}$ & $3194 \pm 692$ & $\begin{array}{l}4812 \pm 973 \\
9583+1103 * *\end{array}$ \\
\hline Isoproterenol & & & & \\
\hline
\end{tabular}

* vs WT with $P<0.001$; ** vs WT HFD with $P<0.001$. Values are expressed as mean \pm SEM of 6 animals per group. 
A

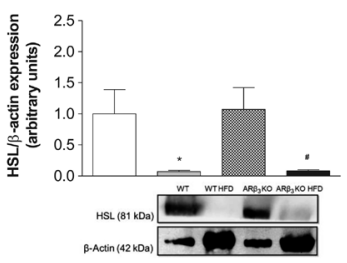

D

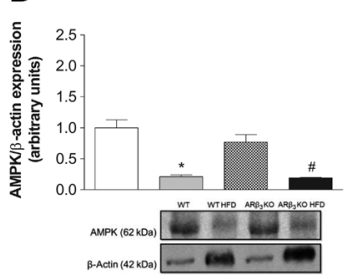

G

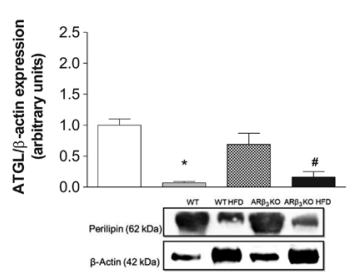

B

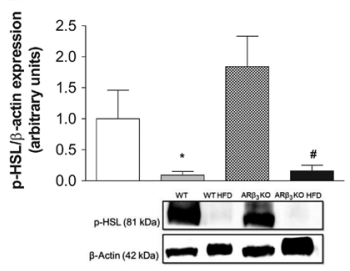

E

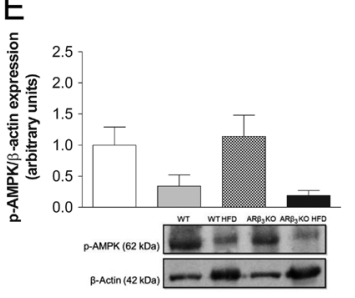

$\mathrm{H}$

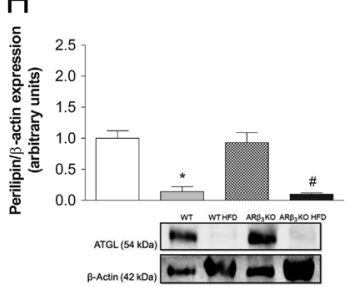

C

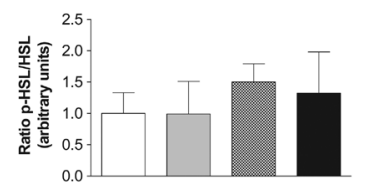

$F$

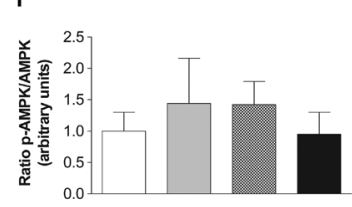

Figure 7

Expression of lipolytic and lipogenic enzymes in epididymal white fat of WT and $A R \beta_{3} K O$ fed with chow or HFD for 8 weeks $(n=6)$. (A) Hormonesensitive lipase (HSL); (B) phosporylated hormone-sensitive lipase ( $p$-HSL); (C) ratio between HSL and p-HSL; (D) AMP-activated protein kinase (AMPk); (E) phosporylated AMP-activated protein kinase (p-AMPk); (F) ratio between AMPk and p-AMPk; (G) adipose triglyceride lipase (ATGL); $(\mathrm{H})$ perilipin and (I) diacylglycerol acyltransferase-2 (DGAT2). * vs WT with $P<0.05$; \# vs AR $\beta_{3} \mathrm{KO}$ with $P<0.05$. Values expressed as mean \pm SEM and data were analyzed using one-way ANOVA followed by Student-Newman-Keuls test.
In conclusion, this study indicates that the $A R \beta_{3}$ plays a fundamental role in the regulation of body weight by mediating adrenergic stimulation of WAT lipolysis, particularly when the adipocytes are loaded with triglycerides. Given the blunted WAT lipolytic response to isoproterenol, the $\mathrm{AR} \beta_{3} \mathrm{KO}$ develops much greater susceptibility to diet-induced obesity with WAT inflammation and more severe hepatic steatosis.

\section{Declaration of interest}

The authors declare that there is no conflict of interest that could be perceived as prejudicing the impartiality of the research reported.

\section{Funding}

This work was supported by Fundação de Amparo à Pesquisa do Estado de São Paulo (FAPESP Grants 2009/50353-1 and 2015/19259-0) and Coordenação de Aperfeiçoamento de Pessoal de Nível Superior (CAPES).

\section{Author contribution statement}

N Z P, B P P N, F S H, C R M, A L V A and T S H conceived and carried out experiments; $F S E, C L L, M L B$ Jr, A C B and M O R conceived experiments and analyzed data. All authors were involved in writing the paper and had final approval of the submitted and published versions.

\section{References}

Arch JR \& Wilson S 1996 Prospects for beta 3-adrenoceptor agonists in the treatment of obesity and diabetes. International Journal of Obesity and Related Metabolic Disorders 20 191-199.

Asensio C, Jimenez M, Kuhne F, Rohner-Jeanrenaud F \& Muzzin P 2005 The lack of beta-adrenoceptors results in enhanced insulin sensitivity in mice exhibiting increased adiposity and glucose intolerance. Diabetes 54 3490-3495. (doi:10.2337/diabetes.54.12.3490)

Atgie C, D'Allaire F \& Bukowiecki LJ 1997 Role of beta1- and beta3adrenoceptors in the regulation of lipolysis and thermogenesis in rat brown adipocytes. American Journal of Physiology 273 C1136-C1142.

Bachman ES, Dhillon H, Zhang CY, Cinti S, Bianco AC, Kobilka BK \& Lowell BB 2002 BetaAR signaling required for diet-induced thermogenesis and obesity resistance. Science 297 843-845. (doi:10.1126/science.1073160)

Batista ML Jr, Henriques FS, Neves RX, Olivan MR, Matos-Neto EM, Alcantara PS, Maximiano LF, Otoch JP, Alves MJ \& Seelaender M 2016 Cachexia-associated adipose tissue morphological rearrangement in gastrointestinal cancer patients. Journal of Cachexia, Sarcopenia and Muscle 7 37-47. (doi:10.1002/jcsm.12037)

Bianco AC, Anderson G, Forrest D, Galton VA, Gereben B, Kim BW, Kopp PA, Liao XH, Obregon MJ, Peeters RP, et al. 2014 American thyroid association guide to investigating thyroid hormone economy and action in rodent and cell models. Thyroid 24 88-168. (doi:10.1089/thy.2013.0109)

Cannon B \& Nedergaard J 2004 Brown adipose tissue: function and physiological significance. Physiological Reviews 84 277-359. (doi:10.1152/physrev.00015.2003)

Carpene C, Galitzky J, Collon P, Esclapez F, Dauzats M \& Lafontan M 1993 Desensitization of beta-1 and beta-2, but not beta-3, adrenoceptor-mediated lipolytic responses of adipocytes after long-term norepinephrine infusion. Journal of Pharmacology and Experimental Therapeutics 265 237-247. 
Chruscinski AJ, Rohrer DK, Schauble E, Desai KH, Bernstein D \& Kobilka BK 1999 Targeted disruption of the beta2 adrenergic receptor gene. Journal of Biological Chemistry 274 16694-16700. (doi:10.1074/ jbc.274.24.16694)

Cinti S 2006 The role of brown adipose tissue in human obesity. Nutrition, Metabolism and Cardiovascular Diseases 16 569-574. (doi:10.1016/j.numecd.2006.07.009)

Collins S, Daniel KW, Rohlfs EM, Ramkumar V, Taylor IL \& Gettys TW 1994 Impaired expression and functional activity of the beta 3and beta 1-adrenergic receptors in adipose tissue of congenitally obese (C57BL/6J ob/ob) mice. Molecular Endocrinology 8 518-527. (doi:10.1210/me.8.4.518)

Cypess AM, Lehman S, Williams G, Tal I, Rodman D, Goldfine AB, Kuo FC, Palmer EL, Tseng YH, Doria A, et al. 2009 Identification and importance of brown adipose tissue in adult humans. New England Journal of Medicine 360 1509-1517. (doi:10.1056/ NEJMoa0810780)

Enerback S, Jacobsson A, Simpson EM, Guerra C, Yamashita H, Harper ME \& Kozak LP 1997 Mice lacking mitochondrial uncoupling protein are cold-sensitive but not obese. Nature 387 90-94. (doi:10.1038/387090a0)

Fernandes GW, Ueta CB, Fonseca TL, Gouveia CH, Lancellotti CL, Brum PC, Christoffolete MA, Bianco AC \& Ribeiro MO 2014 Inactivation of the adrenergic receptor beta2 disrupts glucose homeostasis in mice. Journal of Endocrinology 221 381-390. (doi:10.1530/JOE-13-0526)

Fisher MH, Amend AM, Bach TJ, Barker JM, Brady EJ, Candelore MR, Carroll D, Cascieri MA, Chiu SH, Deng L, et al. 1998 A selective human beta3 adrenergic receptor agonist increases metabolic rate in rhesus monkeys. Journal of Clinical Investigation $1012387-2393$. (doi:10.1172/JCI2496)

Hibi M, Oishi S, Matsushita M, Yoneshiro T, Yamaguchi T, Usui C, Yasunaga K, Katsuragi Y, Kubota K, Tanaka S, et al. 2016 Brown adipose tissue is involved in diet-induced thermogenesis and wholebody fat utilization in healthy humans. International Journal of Obesity [in press]. (doi:10.1038/ijo.2016.124)

Inokuma K, Okamatsu-Ogura Y, Omachi A, Matsushita Y, Kimura K, Yamashita H \& Saito M 2006 Indispensable role of mitochondrial UCP1 for antiobesity effect of beta3-adrenergic stimulation. American Journal of Physiology: Endocrinology and Metabolism 290 E1014-E1021. (doi:10.1152/ajpendo.00105.2005)

Jimenez M, Leger B, Canola K, Lehr L, Arboit P, Seydoux J, Russell AP, Giacobino JP, Muzzin P \& Preitner F 2002 Beta(1)/beta(2)/beta(3)adrenoceptor knockout mice are obese and cold-sensitive but have normal lipolytic responses to fasting. FEBS Letters 530 37-40. (doi:10.1016/S0014-5793(02)03387-2)

Kajimura S \& Saito M 2014 A new era in brown adipose tissue biology: molecular control of brown fat development and energy homeostasis. Annual Review of Physiology 76 225-249. (doi:10.1146/annurevphysiol-021113-170252)

Lafontan M, Barbe P, Galitzky J, Tavernier G, Langin D, Carpene C, Bousquet-Melou A \& Berlan M 1997 Adrenergic regulation of adipocyte metabolism. Human Reproduction 12 (Supplement 1) 6-20. (doi:10.1093/humrep/12.suppl_1.6)

Lee YH, Mottillo EP \& Granneman JG 2014 Adipose tissue plasticity from WAT to BAT and in between. Biochimica et Biophysica Acta 1842 358-369. (doi:10.1016/j.bbadis.2013.05.011)

Lidell ME \& Enerback S 2010 Brown adipose tissue - a new role in humans? Nature Reviews Endocrinology 6 319-325. (doi:10.1038/ nrendo.2010.64)

Lowell BB 1998 Using gene knockout and transgenic techniques to study the physiology and pharmacology of beta3-adrenergic receptors. Endocrine Journal 45 (Supplement) S9-S13. (doi:10.1507/endocrj.45.Suppl_S9)

Lowell BB \& Spiegelman BM 2000 Towards a molecular understanding of adaptive thermogenesis. Nature 404 652-660. (doi:10.1038/35007527)
Mattsson CL, Csikasz RI, Chernogubova E, Yamamoto DL, Hogberg HT, Amri EZ, Hutchinson DS \& Bengtsson T 2011 beta(1)-Adrenergic receptors increase UCP1 in human MADS brown adipocytes and rescue cold-acclimated beta(3)-adrenergic receptor-knockout mice via nonshivering thermogenesis. American Journal of Physiology: Endocrinology and Metabolism 301 E1108-E1118.

Nagase I, Sasaki N, Tsukazaki K, Yoshida T, Morimatsu M \& Saito M 1994 Hyperplasia of brown adipose tissue after chronic stimulation of beta 3-adrenergic receptor in rats. Japanese Journal of Veterinary Research 42 137-145.

Revelli JP, Preitner F, Samec S, Muniesa P, Kuehne F, Boss O, Vassalli JD, Dulloo A, Seydoux J, Giacobino JP, et al. 1997 Targeted gene disruption reveals a leptin-independent role for the mouse beta3adrenoceptor in the regulation of body composition. Journal of Clinical Investigation 100 1098-1106. (doi:10.1172/JCI119620)

Ribeiro MO, Carvalho SD, Schultz JJ, Chiellini G, Scanlan TS, Bianco AC $\&$ Brent GA 2001 Thyroid hormone - sympathetic interaction and adaptive thermogenesis are thyroid hormone receptor isoform specific. Journal of Clinical Investigation 108 97-105. (doi:10.1172/ JCI200112584)

Rodbell M 1964 Metabolism of isolated fat cells. I. Effects of hormones on glucose metabolism and lipolysis. Journal of Biological Chemistry 239 $375-380$.

Rohrer DK 1998 Physiological consequences of beta-adrenergic receptor disruption. Journal of Molecular Medicine 76 764-772. (doi:10.1007/ s001090050278)

Ruderman NB, Schneider SH \& Berchtold P 1981 The 'metabolicallyobese,' normal-weight individual. American Journal of Clinical Nutrition 34 1617-1621.

Rutkowski JM, Stern JH \& Scherer PE 2015 The cell biology of fat expansion. Journal of Cell Biology 208 501-512. (doi:10.1083/jcb.201409063)

Santulli G, Lombardi A, Sorriento D, Anastasio A, Del Giudice C, Formisano P, Beguinot F, Trimarco B, Miele C \& Iaccarino G 2012 Agerelated impairment in insulin release: the essential role of beta(2)adrenergic receptor. Diabetes 61 692-701. (doi:10.2337/db11-1027)

Silva JE 2011 Physiological importance and control of non-shivering facultative thermogenesis. Frontiers in Bioscience 3 352-371. (doi:10.2741/s156)

Soloveva V, Graves RA, Rasenick MM, Spiegelman BM \& Ross SR 1997 Transgenic mice overexpressing the beta 1-adrenergic receptor in adipose tissue are resistant to obesity. Molecular Endocrinology 11 27-38. (doi:10.1210/me.11.1.27)

Sun K, Kusminski CM \& Scherer PE 2011 Adipose tissue remodeling and obesity. Journal of Clinical Investigation 121 2094-2101. (doi:10.1172/ JCI45887)

Sun K, Tordjman J, Clement K \& Scherer PE 2013 Fibrosis and adipose tissue dysfunction. Cell Metabolism 18 470-477. (doi:10.1016/ j.cmet.2013.06.016)

Susulic VS, Frederich RC, Lawitts J, Tozzo E, Kahn BB, Harper ME, Himms-Hagen J, Flier JS \& Lowell BB 1995 Targeted disruption of the beta 3-adrenergic receptor gene. Journal of Biological Chemistry 270 29483-29492. (doi:10.1074/jbc.270.49.29483)

Ueta CB, Fernandes GW, Capelo LP, Fonseca TL, Maculan FD, Gouveia CH, Brum PC, Christoffolete MA, Aoki MS, Lancellotti CL, et al. 2012 beta(1) Adrenergic receptor is key to cold- and dietinduced thermogenesis in mice. Journal of Endocrinology 214 359-365. (doi:10.1530/JOE-12-0155)

van der Lans AA, Wierts R, Vosselman MJ, Schrauwen P, Brans B \& van Marken Lichtenbelt WD 2014 Cold-activated brown adipose tissue in human adults: methodological issues. American Journal of Physiology: Regulatory, Integrative and Comparative Physiology 307 R103-R113. (doi:10.1152/ajpregu.00021.2014)

van Marken Lichtenbelt WD, Vanhommerig JW, Smulders NM, Drossaerts JM, Kemerink GJ, Bouvy ND, Schrauwen P \& Teule GJ 2009 Cold-activated brown adipose tissue in healthy men. http://joe.endocrinology-journals.org

DOI: 10.1530/JOE-16-0199
๑ 2016 Society for Endocrinology Printed in Great Britain 
New England Journal of Medicine 360 1500-1508. (doi:10.1056/ NEJMoa0808718)

Weigle DS 1994 Appetite and the regulation of body composition. FASEB Journal 8 302-310.

Widen E, Lehto M, Kanninen T, Walston J, Shuldiner AR \& Groop LC 1995 Association of a polymorphism in the beta 3-adrenergic-receptor gene with features of the insulin resistance syndrome in Finns. New England Journal of Medicine 333 348-351. (doi:10.1056/NEJM199508103330604)
Xiao C, Goldgof M, Gavrilova O \& Reitman ML 2015 Anti-obesity and metabolic efficacy of the beta3-adrenergic agonist, CL316243, in mice at thermoneutrality compared to 22 degrees C. Obesity 23 1450-1459. (doi:10.1002/oby.21124)

Yoneshiro T, Aita S, Matsushita M, Kameya T, Nakada K, Kawai Y \& Saito M 2011 Brown adipose tissue, whole-body energy expenditure, and thermogenesis in healthy adult men. Obesity 19 13-16. (doi:10.1038/oby.2010.105)

Received in final form 15 September 2016

Accepted 26 September 2016

Accepted Preprint published online 26 September 2016
๑) 2016 Society for Endocrinology Printed in Great Britain
Published by Bioscientifica Ltd. 